\title{
A review on the pharmacokinetic properties and toxicity considerations for chloroquine and hydroxychloroquine to potentially treat coronavirus patients
}

\author{
Fatemeh Askarian ${ }^{1} \cdot$ Zahra Firoozi $^{2} \cdot$ Alireza Ebadollahi-Natanzi $^{3} \cdot$ Solmaz Bahrami $^{4} \cdot$ Hamid-Reza Rahimi $^{1,5}$ (i)
}

Received: 8 February 2021 / Revised: 10 April 2021 / Accepted: 7 June 2021 / Published online: 19 July 2021

(c) Korean Society of Toxicology 2021

\begin{abstract}
The SARS-CoV-2 virus, caused a novel emerged coronavirus disease, is growing rapidly worldwide. Few studies have evaluated the efficacy and safety of Chloroquine (CQ), an old antimalarial drug, and Hydroxychloroquine (HCQ) in the treatment of COVID-19 infection. HCQ is derived from CQ by adding a hydroxyl group into it and is a less toxic derivative of CQ for the treatment of COVID-19 infection because it is more soluble. This article summarizes pharmacokinetic properties and toxicity considerations for CQ and HCQ, drug interactions, and their potential efficacy against COVID-19. The authors also look at the biochemistry changes and clinical uses of CQ and HCQ, and supportive treatments following toxicity occurs. It was believed that CQ and HCQ may provide few benefits to COVID-19 patients. A number of factors should be considered to keep the drug safe, such as dose, in vivo animal toxicological findings, and gathering of metabolites in plasma and/or tissues. The main conclusion of this review is that CQ and HCQ with considered to their ADMET properties has major shortcomings and fully irresponsible.
\end{abstract}

Keywords Chloroquine $\cdot$ COVID-19 $\cdot$ Metabolism $\cdot$ Toxicity

\section{Introduction}

In late 2019, the first case of a novel pneumonia caused by a previously unknown pathogen was appeared in China [1]. On 12 January 2020, the World Health Organization (WHO) named this virus as SARS-CoV-2 as the cause of 2019 novel coronavirus infectious disease (COVID-19) [2, 3]. COVID19 could be dangerous, especially for the old persons [4].

Hamid-Reza Rahimi

hamidrrt@yahoo.com; h_rahimi@kmu.ac.ir

1 Student Research Committee, Faculty of Pharmacy, Kerman University of Medical Sciences, Kerman, Iran

2 Department of Medical Genetics, School of Medicine, Kerman University of Medical Sciences, Kerman, Iran

3 Medicinal Plants Department, Imam Khomeini Higher Education Center, Agricultural Research, Education and Extension Organization (AREEO), Karaj, Iran

4 Department of Institutional Research, Westcliff University, Irvine, CA 92614, USA

5 Department of Pharmacology and Toxicology, Faculty of Pharmacy, Kerman University of Medical Sciences, Kerman, Iran
According to the WHO, as of August, 16, 2020, there are $21,294,845$ confirmed cases and 761,779 deaths [5]. The virus binds to epithelial cells of the nasal cavity and replicates, and ACE2 is the main receptor for COVID-19 [6]. The number of CD8 + and CD4 + T cells in the peripheral blood of COVID-19-infected patients is significantly decreased. Acute respiratory distress syndrome (ARDS) is the common immunopathological event and main death cause of COVID19 [7, 8]. Cytokine storm is one of the main mechanisms for ARDS, which cause multiple organ failure, and finally lead to death in severe cases of multiple organ COVID-19 infection [7].

In 2003, at the time of the SARS-associated coronavirus epidemic [9], several drugs had been evaluated to assess their effectiveness on this virus; one of them is chloroquine (CQ) [10]. These findings have been forgotten, because of the disappearance of SARS for reasons that are neither clear nor explained [11]. Also, studies showed the in vitro activity of CQ against COVID-19 [12]. CQ and Hydroxychloroquine (HCQ) are both being considered for the treatment of COVID-19 [13].

CQ is an aminoquinolone derivative first developed for the treatment of malaria within the 1940s [14]. It was a 
first-line drug for the prophylaxis and treatment of malaria until the development of newer antimalarial drugs like mefloquine, artemisinin, and pyrimethamine $[15,16]$. CQ is also may apply to treat extra-intestinal amebiasis, systemic lupus erythematosus (SLE), and rheumatoid arthritis (RA) $[17,18]$. HCQ is the other 4-aminoquinoline derivatives antimalarial drug synthesized in 1946 and is derived from CQ by adding a hydroxyl group into it [19]. This change makes HCQ more soluble and safer than CQ [20, 21]. It was used to treat rheumatic diseases such as juvenile idiopathic arthritis (JIA), SLE, RA, and Sjogren's syndrome [18].

HCQ and CQ are relatively safe, and the most common side effects include dermatological changes, pruritus, gastrointestinal symptoms and that can occur in up to $10 \%$ of the patients. The most severe side effects include cardiotoxicity, neuromyopathy of proximal muscles, and irreversible retinopathy which have low incidence [22, 23]. Pharmacokinetic and pharmacodynamic properties of HCQ are similar to that of CQ [24]. Due to low therapeutic index and pharmacological activities of its metabolites, assessment of CQ pharmacokinetic is necessary for its optimal clinical use [25].

Therefore, in the face of relevance of HCQ and CQ in COVID-19 pandemic, we discuss here the pharmacokinetic properties and toxicity considerations and mechanisms of CQ obtained from clinical use of this drug in different diseases. These should be considered when using HCQ and CQ for treating COVID-19-associated pneumonia.

\section{Clinical uses}

Antimalarial drugs such as the phosphate and sulfate salts of CQ have been used in the treatment and prevention of malaria [26]. Through CQ anti-histaminic activity in human, it can produce anti-inflammatory effects [27]. The in vitro antiviral activity of HCQ and CQ is that they could affect the growth of many different viruses such as SARS coronavirus [28], enterovirus EV-A71[29], Zika virus [30] and influenza A H5N1[31]. In a nonhuman primate model of CHIKV infection, CQ exacerbated severe fever and delayed the cellular immune response, caused an insufficient viral clearance [32]. CQ could be used for the treatment of infections caused by viruses requiring an acidic $\mathrm{pH}$ for infectivity [33]. CQ has been utilized in the therapy of HIV infection [34] and is additionally used in the medical care of human chronic hepatitis C [35].

Some facts have been reported on the efficacy of CQ in the treatment and prevention of pneumonia caused by COVID-19 at different levels of severity. Gao et al. [36] revealed that CQ phosphate is good in controlling the treatment by prohibiting the aggravation of pneumonia, upgrading lung imaging findings, developing a virus negative conversion, and reducing the disease course.

\section{Mechanism}

CQ has broad-spectrum activity against a range of viral, fungal, and bacterial infections [37-40]. In in vitro study, CQ has antiviral activity against RNA viruses [41]. CQ can interfere with viral particles that bind to their cellular cell surface receptor. It can inhibit quinone reductase 2 [42] that are participated within the biosynthesis of sialic acids [43]. The broad antiviral spectrum of this drug may be because of interference of CQ with sialic acid biosynthesis. Sialic acids are present on cell transmembrane proteins as important components of ligand recognition [44]. So it interferes with the fusion process of SARS virus [44]. The virus use cell surface receptor ACE2, and CQ inhibiting COVID-19 binding to target cell by interfering with glycosylation of ACE2 receptor. SARS-CoV upregulated the ACE2 expression in lung tissue thus viruses' replication and outbreak may increase [45]. By interfering with the $\mathrm{pH}$-dependent endosome-mediated viral entry of enveloped viruses through alkalization of endosomes CQ can impress another stage of virus replication [46-48]. Entry into the endosome could be necessary for the viral genome to be released into the cytoplasm of infected host cells [49]. But how changes in $\mathrm{pH}$ could affect the integrity of viral genome is unclear [50]. It can also interfere with the post-translational modification of viral proteins [51, 52]. So that, by interfering with proteolytic processing of the $\mathrm{M}$ protein, it could alter virion assembly and budding [13]. Also CQ and HCQ inhibit autophagy by preventing the fusion of the autophagosome with the lysosome and deacidifying the lysosome and they have shown efficacy against many different types of viruses [53] including SARS-CoV-2 [54-56].

Through regulation of pro-inflammatory cytokines and cell signaling, CQ can affect the immune system [57]. One of the effects of CQ on the immune system is the enhancement of human cytotoxic CD8 $+\mathrm{T}$ and increasing the cross-presentation of viral antigens [50]. In addition, it can effect on regulation of pro-inflammatory cytokines and cell signaling by inhibiting the Toll-like receptor pathway [58]. Also CQ can inhibit virus replication through inhibition of p38 mitogen-activated protein kinase (MAPK) (Fig. 1) [59-61].

\section{Absorption}

The absorption of CQ was rapid and almost completed; so that it's oral tablets have a bioavailability of $67-114 \%$ [62]. HCQ like CQ is also fully and quickly absorbed after oral administration [63]. When administered with food, the mean plasma peak concentrations were significantly higher but the time to reach the peak concentration 
Fig. 1 Possible effects of CQ on the SARS-CoV-2 replication cycle. (1) CQ interferes with glycosylation of ACE-2 receptor. Also it could limit the biosynthesis of sialic acids that may be required for cell surface binding of SARS-CoV-2. (2) $\mathrm{CQ}$ interferes with the $\mathrm{pH}-$ dependent-endosome-mediated viral entry of enveloped viruses through alkalization of endosome. So, it can inhibit fusion of the viral envelope and phospholipidic membrane of the endosomes resulting in release of the viral genome into the cell cytoplasm. (3) CQ interferes with post translational modification of viral proteins. CQ also interferes with proteolytic processing of the M protein (M protein is interacting with the other proteins of the virus, and plays an essential role during viral assembly) and alter virion assembly and budding. (4) CQ inhibits the activation (phosphorylation) of p38 MAPK. Also, it may inhibit virus replication

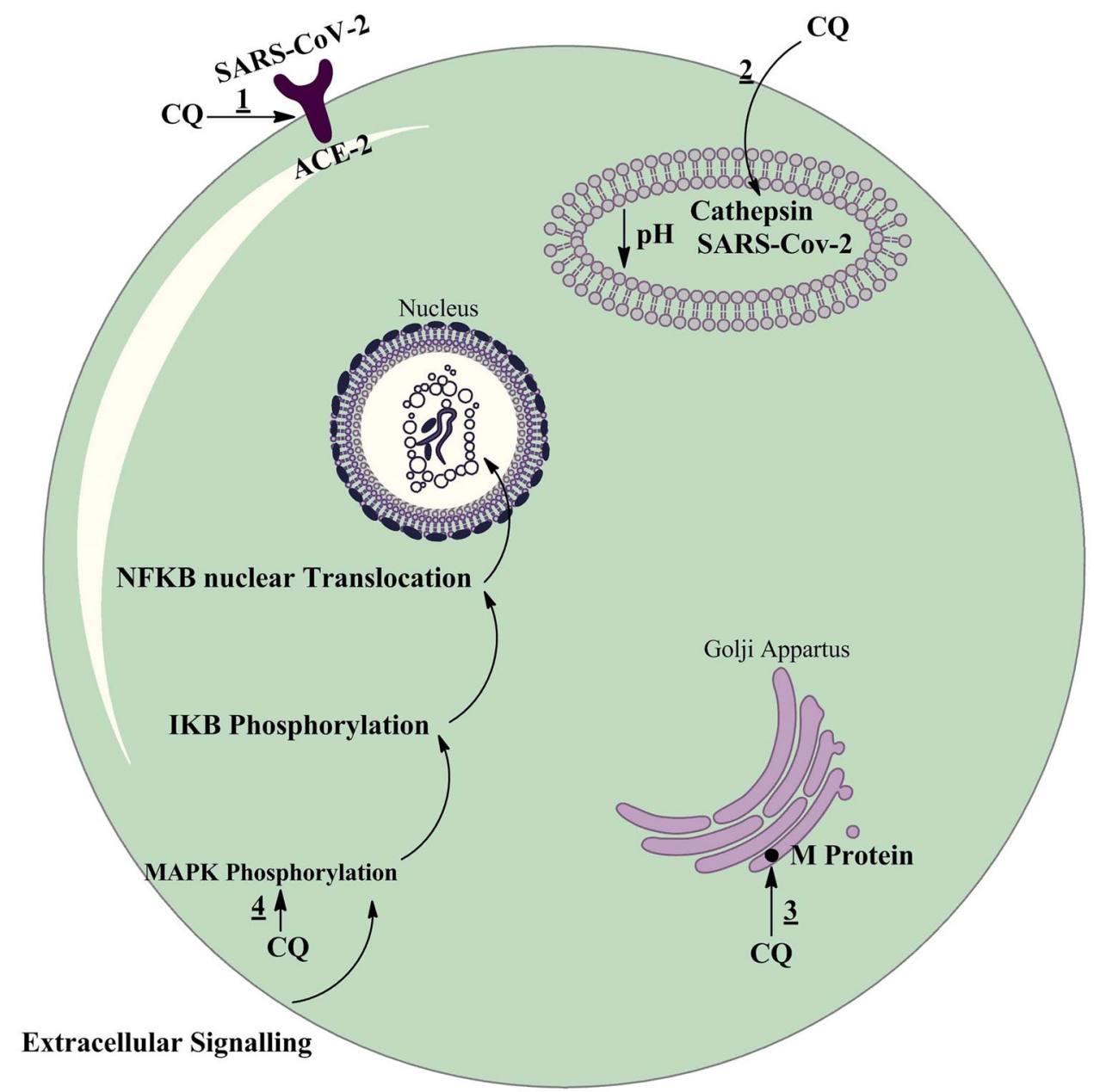

was similar. However, the effect of food seems to be subjected to large inter-individual variability. Also, the bioavailability of CQ is significantly enhanced when given along with food [64].

\section{Distribution}

Apparent volume of distribution (Vd) of CQ is 200-800 $\mathrm{L} / \mathrm{kg}$ when calculated from plasma concentrations, and protein binding of CQ is about 60\% [65-68]. CQ and HCQ accumulate in different tissues in varying concentrations [69]. High concentrations of these drugs are found in the cardiac tissue, lungs, kidneys, liver, skeletal muscle, skin, and eye [69]. Due to significant interindividual pharmacokinetic variability, after administration of standardized doses, variable tissue concentrations might be found [25].

\section{Metabolism}

Following single or multiple doses there are determined interindividual variations in the pharmacokinetics of $\mathrm{CQ}$ [67, 70-74]. About 30-50\% of an administered dose of CQ is transformed by the liver [73]. After administration, CQ is rapidly dealkylated into the pharmacologically active metabolites such as bisdesethylchloroquine (BDCQ), desethylchloroquine (DCQ), and 7-chloro-4-aminoquinoline [64, 65, 70, 72] (Fig. 2). These metabolites have been involved in $\mathrm{CQ}$-induced heart failure (cardiotoxicity) $[74,75]$. It has been demonstrated that BDCQ is more cardiotoxic than CQ [75]. Like CQ, DCQ was showed to be active against the Zika virus [76]. Nonetheless, no data are available on the performance of DCQ in COVID-19 [77]. Studies show the minimal contribution of BDCQ formation in the metabolism of $\mathrm{CQ}$ in comparison with DCQ [77]. 
<smiles>CCN(CC)CCCC(C)Nc1ccnc2cc(Cl)ccc12</smiles>

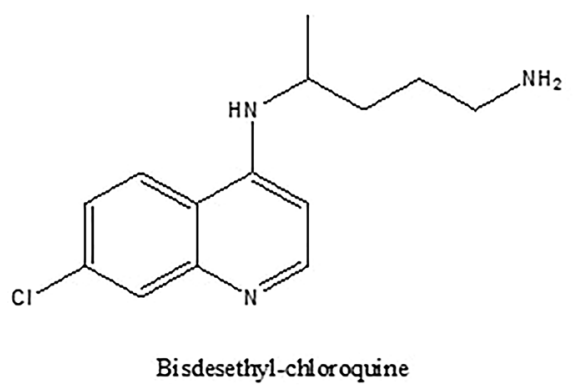<smiles>CCNCCCC(C)Nc1ccnc2cc(Cl)ccc12</smiles><smiles>Nc1ccnc2cc(Cl)ccc12</smiles>

Fig. 2 Chemical structures of chloroquine and of its three main metabolites, bisdesethylchloroquine, desethylchloroquine and 7-chloro4-aminoquinoline (ChemDraw)

CQ and its active metabolites have long half-lives [74]. CQ can be $N$-dealkylated via the cytochrome P450 (CYP) enzyme system $[69,78]$. Individual CYP data indicate that CYP2D6 is a main isoform of CQ metabolism, but different results showing a relatively weak relationship between the CYP2D6 and the formation of DCQ [63]. When the inhibition of the DCQ formation was estimated, by CYPselective inhibitors, ketoconazole (a potent inhibitor of CYP3A4/5) and quercetin (a CYP2C8 inhibitor) showed a significant inhibition [61, 78]. The other CYP-selective chemical inhibitors showed weak inhibition of the metabolism of CQ [61]. So that, the CYP3A4/5 and CYP2C8 are the main enzymes in the CQ N-deethylation into DCQ [61]. Also, HCQ is a substrate of CYP2D6, CYP3A4/5, and CYP2C8 and it leads to CYP2D6 inhibition [79]. It has been indicated that CQ-induced pruritus may be related to the activity of CYP2C8 and CYP3A4/5 [61]. Nonetheless, CYP2D6 and CYP3As are 2 major isoforms involved in and affected by the metabolism of CQ [80].

\section{Excretion}

Both CQ and HCQ concentrations decrease slowly with elimination half-life of twenty to sixty days. Despite its long half-life, CQ has a relatively high total clearance, $0.7-1 \mathrm{~L} / \mathrm{h} /$ $\mathrm{kg}$ from plasma and approximating $0.10 \mathrm{~L} / \mathrm{h} / \mathrm{kg}$ from whole blood. Its excretion is $\geq 50 \%$ as unchanged drug in urine, where acidification of urine will increase its elimination $[66,73]$. Kidneys excreted $50 \%$ of CQ, therefore it is suggested that lowered doses must be consumed in patients with renal impairment. More than $50 \mathrm{mg} /$ day of CQ should not be used in patients with a glomerular filtration rate (GFR) of $10-20 \mathrm{~mL} / \mathrm{min}$ [81].

\section{Toxicity}

1) Nervous toxicity

CQ and HCQ are extremely toxic in overdose. Overdose of CQ and HCQ causes rapid onset of central nervous system toxicity (coma and seizures). CQ and HCQ can cause psychosis, mania, depression, paranoia, catatonia, hallucinations, suicidal ideation agitation, insomnia and confusion during acute or chronic use [82-85].

2) Cardiovascular toxicity

Overdose of CQ and HCQ causes cardiovascular collapse by inhibiting of cardiac potassium and sodium channels, which cause QRS widening and QT interval prolongation and hypokalemia resulting from intracellular shifting [86]. CQ induced cardiac toxicity indicates itself in the form of cardiomyopathy and conduction disorders [87]. Therapeutic doses cause QT interval prolongation, $\mathrm{T}$ wave inversion, and ST-segment 
depression in resting electrocardiogram [88]. Clinical manifestations of congestive heart failure usually occur years after a third degree AV block [89]. Also, cardiovascular collapse and hypotension can occur about $2 \mathrm{~h}$ after overdose [89]. In patients that use CQ for LE and $\mathrm{RA}$, because of increasing number of CQ cardiotoxicity cases at low doses and difficult diagnosis, an electrocardiogram (ECG) should be included with annual ophthalmological check-ups [90-92]. Furthermore, if CQ-induced cardiotoxicity detected early through ECG, it can improve the patient outcome [93].

3) Ocular toxicity

Ocular toxicity is caused by HCQ and CQ to various parts of the eye such as the retina, ciliary body, and cornea. High daily dosage and long exposure associated with toxic retinopathy, and it was the main side effect of CQ and HCQ therapy [94]. HCQ and CQ bind to the melanin of the retinal pigment epithelium (RPE), inhibited RPE lysosome activity and reduced phagocytosis of shed photoreceptor that all resulted in clinical degeneration of RPE cells [95]. Early retinal toxicity may be asymptomatic but patients with advanced stage of toxicity may complain of paracentral scotomas or color vision changes. While toxic retinopathy is usually irreversible, early detection is the best treatment [96]. The risk of retinal toxicity can be kept at low levels through paying attention to appropriate dosing and risk factors such as tamoxifen usage and renal disease [97]. Corneal deposits observed within the first 2 or 3 weeks of HCQ and CQ treatment due to binding of drug to cellular lipids and deposition of the drug in the basal epithelial layer of the cornea. Haloes and glare are symptoms of corneal deposits, and keratopathy appear most often with CQ than HCQ, and these symptoms may also vanish with dose reduction [94].

4) Enhance oxidative stress

Some studies have indicated that CQ inhibited CYP450 activity and lead to inhibition of the mitochondrial functions, and oxidative stress, particularly in erythrocytes $[98,99]$. CQ could enhance oxidative stress by diminishing non-enzymatic and enzymatic antioxidant defenses, and causing DNA damage in brain, liver, and kidney of rats [100]. Studies have demonstrated that ROS (reactive oxygen species) arising, a metabolite of $\mathrm{CQ}$, mediated oxidative stress and affect antioxidant enzymes in humans $[101,102]$.

5) Serum abnormalities

Omotosho et al. [103, 104] studied on hematology and serum biochemistry of male Wistar rats treated with CQ and showed that there is a significant decrease in a type of infection-fighting WBC called neutrophils in CQ treated group. CQ can suppress the cytokine storm in COVID-19 patients through inhibiting the production and release of IFN $\gamma$, IL-1, IL-6, and TNF $\alpha$.

There was a considerable increase in serum creatinine level in the CQ treated group, which is usually seen in renal functional impairment. AST and ALT levels were significantly elevated, which shows that therapy with CQ has the potential of causing skeletal muscle, erythrocytes, hepatocytes, or necrosis of the myocardial cells that may be related to duration and dose of the therapy [104]. Also hypokalemia is present in overdose [105].

6) Other toxicities

Other toxicities of CQ include affecting on serum glucose levels and caused hypoglycemia through increasing insulin sensitivity, reducing insulin clearance, and enhancing pancreatic insulin release [106, 107], interfering with hemoglobin $(\mathrm{Hb})$ clearance pathway, thereby inhibiting heme detoxification, heme-iron recycling, and causing anemia [108], neuromuscular effects such as myopathy [93], and extrapyramidal syndrome [109]. CQ and HCQ interfere with ventricular repolarization, causing QT prolongation, which could increase the risk of torsades de pointes [110]. Pruritus, headaches, dizziness, and gastrointestinal upset are common, non-ocular side effects of CQ and HCQ and discoloration of hair, skin, nails, and the oral cavity are the other rare side effects [111]. Hearing loss is typically bilateral, mild to moderate, and may be accompanied by vestibular dysfunction including vertigo [112].

Due to lower level of tissue accumulation, HCQ has fewer side effects than CQ [58]. While CQ exerts different severe side events on fetal development, HCQ is strongly suggested for pregnant patients with an autoimmune disorder because it prevents the event of development of inborn heart block because of a possible inhibitory effect of production of type I interferon (INF-I) [113, 114]. The outbreak of SARS-CoV-2 has engaged several pregnant females at high risk of infection; HCQ, instead of CQ, must be considered as a suitable therapy for these patients, given its safety profile in pregnancy condition $[115,116]$. Some examples of the toxicity/ side effects of CQ and HCQ in human, animal and cell lines are listed in Table 1.

\section{Possible drug interaction}

Pharmacodynamic drug-drug interactions (DDIs) occur when there is an antagonistic or synergistic effect of two or more drugs at a specific receptor site. Combinations of HCQ and CQ with other QT-prolonging medications, such as anti-emetics (e.g. ondansetron, droperidol, haloperidol, and promethazine), amiodarone, tricyclic antidepressants, quinolones, methadone, and numerous others may elevate 
Table 1 The toxicity/side effects of CQ and HCQ in human, animal and cell line

\begin{tabular}{|c|c|c|c|c|c|c|c|}
\hline Drug & $\begin{array}{l}\text { Concentration/ } \\
\text { dose }\end{array}$ & $\begin{array}{l}\text { Route of adminis- } \\
\text { tration }\end{array}$ & Duration & Species/cell line & $\begin{array}{l}\text { Toxicity/side } \\
\text { effects }\end{array}$ & $\begin{array}{l}\text { Mechanism of } \\
\text { toxicity }\end{array}$ & References \\
\hline CQ & $\begin{array}{l}25,50,75,100 \text { and } \\
500 \mu \mathrm{M}\end{array}$ & - & 12,24 and $48 \mathrm{~h}$ & Schwann cells & $\begin{array}{l}\text { Inner glial cells } \\
\text { toxicity }\end{array}$ & $\begin{array}{l}\text { Ascorbic acid } \\
\text { prevented CQ- } \\
\text { induced ROS } \\
\text { production and } \\
\text { CQ toxicity }\end{array}$ & [113] \\
\hline CQ & $10-250 \mu \mathrm{M}$ & - & $24 \mathrm{~h}$ & ARPE-19 Cells & Retinotoxicity & $\begin{array}{l}\text { Activation of } \\
\text { autophagy and } \\
\text { causing cell } \\
\text { death }\end{array}$ & [114] \\
\hline CQ & $50 \mathrm{mg} / \mathrm{kg} /$ day & Oral & 4 weeks & Rat & Kidney toxicity & $\begin{array}{l}\text { Inhibiting cAMP/ } \\
\text { PKA/AKT sign- } \\
\text { aling pathway }\end{array}$ & [115] \\
\hline CQ & $32 \mathrm{mg} / \mathrm{kg}$ & Subcutaneously & 1 day & Female Mice & Pruritus side effect & $\begin{array}{l}\text { Green synthesized } \\
\text { ZnO NPs affect } \\
\text { the CQ-induced } \\
\text { pruritus }\end{array}$ & [116] \\
\hline CQ & $50 \mathrm{mg} / \mathrm{kg} /$ day & Oral & 2 months & Rat & Cardio toxicity & $\begin{array}{l}\text { Via up-regulation } \\
\text { of Rho-kinase } 1\end{array}$ & [117] \\
\hline CQ & $\begin{array}{l}\text { a) } 100-300 \mathrm{~g} \\
\text { b) }>300 \mathrm{~g} \\
\text { c) Patients who } \\
\text { never received } \\
\text { chloroquine }\end{array}$ & Oral & 3 months & Human & Macular toxicity & $\begin{array}{l}\text { Depends on APO } \\
\text { E genotype }\end{array}$ & [118] \\
\hline CQ and HCQ & $\begin{array}{l}\text { a) CQ: } 250- \\
500 \mathrm{mg} / \text { day } \\
\text { b) HCQ: } 200- \\
400 \mathrm{mg} / \text { day }\end{array}$ & Oral & 2 months & Human & Ocular toxicity & $\begin{array}{l}\text { HCQ has a sig- } \\
\text { nificantly lower } \\
\text { risk of causing } \\
\text { ocular toxicity } \\
\text { than CQ for its } \\
\text { more solubility }\end{array}$ & [119] \\
\hline
\end{tabular}

$A K T$ protein kinase B, APO E apolipoprotein E, APE-19 a human retinal pigment epithelial cell line, $c A M P$ cyclic adenosine monophosphate, $C Q$ chloroquine, $H C Q$ hydroxychloroquine, $N P s$ nanoparticles, $P K A$ protein kinase $\mathrm{A}, R O S$ reactive oxygen species

the risk of developing a toxic arrhythmia such as ventricular fibrillation [117]. Combination of azithromycin and HCQ, one of the regimens which used for treatment of COVID-19, could theoretically increase the risk of torsades de pointes [118].

CQ and HCQ are both inhibitors of P-glycoprotein (P-gp) transport system, which is an efflux transporter, found in blood-brain barrier endothelial cells and gut luminal [119]. HCQ can increase digoxin levels and both of CQ and HCQ increasing cyclosporine levels, so they are attributable to HCQ and CQ inhibiting P-gp activity, insofar as both digoxin and cyclosporine are well-known substrates of this cellular pump. Additionally, there are several reports of the interaction of CQ and cyclosporine [120]. There is an increased risk for a more severe and more frequent COVID-19 clinical course for immunologically-challenged patients, so, clinicians should be especially aware of these DDIs [117].

The main family of enzymes which is responsible for oxidative metabolism of many drugs is CYP P450 system. The main metabolic enzymes of CQ and HCQ include
CYP3A4/5, CYP2C8, and CYP2D6 [61, 77]. Polymorphisms in these enzymes can alter disposition [121].

Cimetidine is a CYP450 pan-inhibitor. Cimetidine leads enzymatic inhibition after several days. Then, $\mathrm{HCQ} /$ cimetidine and/or $\mathrm{CQ} /$ cimetidine co-administration results in possible increases in both HCQ and CQ levels [122]. Clinicians should also be aware that co-administration of CYP 3A4/5 inhibitors (ciprofloxacin, most macrolide antibiotics, azole anti-fungal agents, diltiazem, and verapamil, among others) and CYP2C8 inhibitors (clopidogrel and gemfibrozil) may increase the blood levels of HCQ and CQ [117]. The ability of CQ and HCQ to inhibit CYP2D6 might reduce the analgesic efficacy of opioids which are metabolised by CYP2D6 [123, 124].

Also, the co-administration of CQ with other drugs or substances that are substrates of the CYP enzymes (e.g., paracetamol and ethanol) can result in adverse effects to the kidney [125-127]. 


\section{Supportive treatment and recommendation}

Current advanced ocular examination methods like optical coherence tomography (OCT), multifocal electroretinography, and fundus autofluorescence have allowed earlier recognition of retinopathy, often before patients experience symptoms $[128,129]$. Once definitive symptoms of retinopathy are known, the choice to prevent medication should be created in conjunction with the patient and the prescribing physician to make sure that medical risks are controlled. The patient will be advised about the danger of further visual loss counting on the severity of the retinopathy [130]. Patients with age-related maculopathy or macular dystrophies generally are suggested to continue intake of zeaxanthin and lutein and keep away from sun exposure [94, 95]. The most necessary changes in practice guidelines include dose calculation supported total weight, dose reduction after long-term use, and intense screening with techniques including OCT after 5 years [23].

Use of general treatments including gastric lavage, fluid resuscitation, sodium bicarbonate, or single-or multiple-dose activated charcoal, were important elements in the treatment of CQ overdose. Administrations of diazepam and epinephrine and mechanical ventilation have been proposed as important factors in CQ poisoning situations [131, 132]. In addition, intravenous thiopentone administration could be effective in the treatment of cardiac arrest of patients poisoned with CQ [133]. Also, administration of hypertonic saline or sodium bicarbonate could be beneficial for substantial QRS widening and arrhythmia [134]. Studies suggest that free radical scavenging and antioxidant activity of lipoate may prevent the CQ-induced lipid peroxidation. So, lipoic acid can protect renal tissue from CQ-induced oxidative damage [135].

Stopping the drug, using supplemental glucose or parenteral dextrose, and administration of octreotide (50-100 $\mu \mathrm{g}$ subcutaneously Queryor intravenously every $8 \mathrm{~h}$ ) are supportive treatments for management of hypoglycemia [136].

Resolution of neuropsychiatric effects is predicated upon stopping the drug, although symptoms might not resolve immediately [137].

\section{Conclusion}

For decades, CQ has been applied for the treatment of various diseases and disorders. CQ and HCQ are antimalarial, antiamoebic, immunomodulatory, and potential broad-spectrum antiviral drugs. Studies have suggested CQ and HCQ can interfere with ACE2 receptors glycosylation of the coronavirus, increase endosomal $\mathrm{pH}$, interfere with post translational modification of viral proteins, inhibit the activation of p38 MAPK thus inhibiting viral fusion, decreasing viral load, altering virion assembly and inhibiting virus replication.

Being aware of ADMET considerations for CQ and also biochemical and hematological changes through taking CQ in patients could help us to reach optimal efficacy and lower toxicity. Through the study of pharmacokinetics of CQ, we observed that CQ and HCQ have rapid gastrointestinal absorption [62], a high volume of distribution, long halflives $[66,73]$ and pharmacologically active metabolites [73].

COVID-19 has rapidly increased in epidemic scale since its first appearance in Wuhan, China, in December 2019[138]. There are limited data to support the use of CQ and HCQ for COVID-19. The drugs have some in vitro activity against several viruses, including influenza and coronaviruses, but previous randomized trials in patients with influenza have been negative [139, 140]. One small nonrandomized study from France showed benefit of CQ and HCQ, and a follow-up study still lacked a control group [141, 142]. Another randomized and small study in patients with mild to moderate COVID-19 from China showed no difference in recovery rates [143]. Other clinical trials from China have already shown promising results for using these drugs in COVID-19 [144, 145]. In a small sample size study, HCQ therapy was significantly associated with a reduction in viral load and worked synergistically with azithromycin against COVID-19. In an in vitro study, a similar synergistic effect was obtained in combination therapy of HCQ and azithromycin, as both reduce the acidity of the lysosome to impair viral replication. On the other hand, a high risk of HCQ's QT prolongation was observed with concurrent treatment with azithromycin [141, 146, 147]. Reports of adverse events have increased and several countries reporting poisonings. Common side effects of CQ and HCQ are retinopathy, mental status changes, and hypoglycemia. In patients receiving these drugs, clinical screening for visual and mental disturbances, glucose levels, hepatic and renal function, and monitoring of heart rate and the QT interval are recommended. Recent studies have shown that CQ can decrease in neutrophil count [104] and it could be beneficial in COVID-19 related neutrophilia. COVID-19 can increase secretion of hyperglycemic hormones, and cause hyperglycemia but CQ may decrease serum glucose levels as an adverse effect, so CQ can control COVID-19 induced hyperglycemia. However, there was a significant increase in ALT and AST levels in the CQ treated group, like COVID-19 patients, so the potential of causing necrosis of the hepatocytes, skeletal muscle, erythrocytes, myocardial cells or in CQ treated COVID-19 patients may increase. Also, elevated serum creatinine in CQ treated group especially in COVID-19 patients could increase renal functional impairment. With the multiple DDIs that are currently known, use of CQ and HCQ with other drug therapy requires consideration for patient safety. 
While further clinical trials are required to provide concrete evidence on the use of these agents in COVID-19.

\section{Declarations}

Conflict of interest Authors have no conflicts of interest.

\section{References}

1. Wang L-F, Shi Z, Zhang S, Field H, Daszak P, Eaton BT (2006) Review of bats and SARS. Emerg Infect Dis 12:1834. https://doi. org/10.3201/eid1212.060401

2. Wu F, Zhao S, Yu B, Chen Y-M, Wang W, Song Z-G et al (2020) A new coronavirus associated with human respiratory disease in China. Nature 579:265-269. https://doi.org/10.1038/ s41586-020-2008-3

3. Ge X-Y, Li J-L, Yang X-L, Chmura AA, Zhu G, Epstein JH et al (2013) Isolation and characterization of a bat SARS-like coronavirus that uses the ACE2 receptor. Nature 503:535-538. https:// doi.org/10.1038/nature 12711

4. Wu Z, McGoogan JM (2020) Characteristics of and important lessons from the coronavirus disease 2019 (COVID-19) outbreak in China: summary of a report of 72,314 cases from the Chinese Center for Disease Control and Prevention. JAMA 323(13):1239-1242. https://doi.org/10.1001/jama.2020.2648

5. Organization WH (2020) Coronavirus disease 2019 (COVID-19): situation report. WHO, p 209

6. Hoffmann M, Kleine-Weber H, Schroeder S, Krüger N, Herrler $\mathrm{T}$, Erichsen $\mathrm{S}$ et al (2020) SARS-CoV-2 cell entry depends on ACE2 and TMPRSS2 and is blocked by a clinically proven protease inhibitor. Cell 181:271-280.e8. https://doi.org/10.1016/j. cell.2020.02.052

7. Xu Z, Shi L, Wang Y, Zhang J, Huang L, Zhang C et al (2020) Pathological findings of COVID-19 associated with acute respiratory distress syndrome. Lancet Respir Med 8:420-422. https:// doi.org/10.1016/S2213-2600(20)30076-X

8. Huang C, Wang Y, Li X, Ren L, Zhao J, Hu Y et al (2020) Clinical features of patients infected with 2019 novel coronavirus in Wuhan, China. Lancet 395:497-506. https://doi.org/10.1016/ S0140-6736(20)30183-5

9. Ksiazek TG, Erdman D, Goldsmith CS, Zaki SR, Peret T, Emery $S$ et al (2003) A novel coronavirus associated with severe acute respiratory syndrome. N Engl J Med 348:1953-1966. https://doi. org/10.1056/NEJMoa030781

10. Vincent MJ, Bergeron E, Benjannet S, Erickson BR, Rollin PE, Ksiazek TG et al (2005) Chloroquine is a potent inhibitor of SARS coronavirus infection and spread. Virol J 2:69 https://doi. org/10.1186/1743-422X-2-69

11. Yu IT-S, Qiu H, Tse LA, Wong TW (2014) Severe acute respiratory syndrome beyond Amoy Gardens: completing the incomplete legacy. Clin Infect Dis 58:683-686. https://doi.org/10.1093/ $\mathrm{cid} / \mathrm{cit} 797$

12. Wang M, Cao R, Zhang L, Yang X, Liu J, Xu M et al (2020) Remdesivir and chloroquine effectively inhibit the recently emerged novel coronavirus $(2019-\mathrm{nCoV})$ in vitro. Cell Res 30:269-271. https://doi.org/10.1038/s41422-020-0282-0

13. Devaux CA, Rolain J-M, Colson P, Raoult D (2020) New insights on the antiviral effects of chloroquine against coronavirus: what to expect for COVID-19? Int J Antimicrob Agents 55:105938. https://doi.org/10.1016/j.ijantimicag.2020.105938

14. Tse EG, Korsik M, Todd MH (2019) The past, present and future of anti-malarial medicines. Malar J 18:93. https://doi.org/10. 1186/s12936-019-2724-Z
15. Sriboonvorakul N, Ghose A, Hassan MMU, Hossain MA, Faiz MA, Pukrittayakamee S et al (2018) Acidosis and acute kidney injury in severe malaria. Malar J 17:128. https://doi.org/10.1186/ s12936-018-2274-9

16. Vandekerckhove S, D'hooghe M (2015) Quinoline-based antimalarial hybrid compounds. Bioorg Med Chem 23:5098-5119. https://doi.org/10.1016/j.bmc.2014.12.018

17. Cabral RTS, Klumb EM, Couto MINN, Carneiro S (2019) Evaluation of toxic retinopathy caused by antimalarial medications with spectral domain optical coherence tomography. Arq Bras Oftalmol 82:12-17. https://doi.org/10.5935/0004-2749.20190 002

18. Jorge A, Ung C, Young LH, Melles RB, Choi HK (2018) Hydroxychloroquine retinopathy-implications of research advances for rheumatology care. Nat Rev Rheumatol 14:693-703. https://doi. org/10.1038/s41584-018-0111-8

19. McChesney EW (1983) Animal toxicity and pharmacokinetics of hydroxychloroquine sulfate. Am J Med 75:11-18. https://doi. org/10.1016/0002-9343(83)91265-2

20. Plantone D, Koudriavtseva T (2018) Current and future use of chloroquine and hydroxychloroquine in infectious, immune, neoplastic, and neurological diseases: a mini-review. Clin Drug Investig 38:653-671. https://doi.org/10.1007/s40261-018-0656-y

21. Page $F(1951)$ Treatment of lupus erythematosus with mepacrine. Lancet 258:755-758. https://doi.org/10.1016/S0140-6736(51) 91643-1

22. Wallace DJ, Trobe J (2020) Antimalarial drugs in the treatment of rheumatic disease. UpToDate, Waltham

23. Abdulaziz N, Shah AR, McCune WJ (2018) Hydroxychloroquine: balancing the need to maintain therapeutic levels with ocular safety an update. Curr Opin Rheumatol 30:249-255. https://doi.org/10.1097/BOR.0000000000000500

24. Wellems TE, Plowe CV (2001) Chloroquine-resistant malaria. J Infect Dis 184:770-776. https://doi.org/10.1086/322858

25. Ducharme J, Farinotti R (1996) Clinical pharmacokinetics and metabolism of chloroquine. Clin Pharmacokinet 31:257-274. https://doi.org/10.2165/00003088-199631040-00003

26. Frisk-Holmberg M, Bergqvist Y, Englund U (1983) Chloroquine intoxication. Br J Clin Pharmacol 15:502. https://doi. org/10.1111/j.1365-2125.1983.tb01540.x

27. Rainsford K, Parke AL, Clifford-Rashotte M, Kean W (2015) Therapy and pharmacological properties of hydroxychloroquine and chloroquine in treatment of systemic lupus erythematosus, rheumatoid arthritis and related diseases. Inflammopharmacology 23:231-269. https://doi.org/10.1007/ s10787-015-0239-y

28. Keyaerts E, Vijgen L, Maes P, Neyts J, Van Ranst M (2004) In vitro inhibition of severe acute respiratory syndrome coronavirus by chloroquine. Biochem Biophys Res Commun 323:264-268. https://doi.org/10.1016/j.bbrc.2004.08.085

29. Tan YW, Yam WK, Sun J, Chu JJH (2018) An evaluation of chloroquine as a broad-acting antiviral against hand, foot and mouth disease. Antivir Res 149:143-149. https://doi.org/10. 1016/j.antiviral.2017.11.017

30. Li C, Zhu X, Ji X, Quanquin N, Deng Y-Q, Tian M et al (2017) Chloroquine, a FDA-approved drug, prevents Zika virus infection and its associated congenital microcephaly in mice. EBioMedicine 24:189-194. https://doi.org/10.1016/j.ebiom.2017. 09.034

31. Yan Y, Zou Z, Sun Y, Li X, Xu K-F, Wei Y et al (2013) Antimalaria drug chloroquine is highly effective in treating avian influenza A H5N1 virus infection in an animal model. Cell Res 23:300-302. https://doi.org/10.1038/cr.2012.165

32. Roques P, Thiberville S-D, Dupuis-Maguiraga L, Lum F-M, Labadie K, Martinon F et al (2018) Paradoxical effect of 
chloroquine treatment in enhancing chikungunya virus infection. Viruses 10:268. https://doi.org/10.3390/v10050268

33. Akpovwa $\mathrm{H}$ (2016) Chloroquine could be used for the treatment of filoviral infections and other viral infections that emerge or emerged from viruses requiring an acidic $\mathrm{pH}$ for infectivity. Cell Biochem Funct 34:191-196. https://doi.org/ 10.1002/cbf.3182

34. Chauhan A, Tikoo A (2015) The enigma of the clandestine association between chloroquine and HIV-1 infection. HIV Med 16:585-590. https://doi.org/10.1111/hiv.12295

35. Peymani P, Yeganeh B, Sabour S, Geramizadeh B, Fattahi MR, Keyvani $\mathrm{H}$ et al (2016) New use of an old drug: chloroquine reduces viral and ALT levels in HCV non-responders (a randomized, triple-blind, placebo-controlled pilot trial). Can J Physiol Pharmacol 94:613-619. https://doi.org/10.1139/ cjpp-2015-0507

36. Gao J, Tian Z, Yang X (2020) Breakthrough: chloroquine phosphate has shown apparent efficacy in treatment of COVID-19 associated pneumonia in clinical studies. Biosci Trends 14:7273. https://doi.org/10.5582/BST.2020.01047

37. Raoult D, Drancourt M, Vestris G (1990) Bactericidal effect of doxycycline associated with lysosomotropic agents on Coxiella burnetii in P388D1 cells. Antimicrob Agents Chemother 34:1512-1514. https://doi.org/10.1128/AAC.34.8.1512

38. Raoult D, Houpikian P, Dupont HT, Riss JM, Arditi-Djiane J, Brouqui P (1999) Treatment of Q fever endocarditis: comparison of 2 regimens containing doxycycline and ofloxacin or hydroxychloroquine. Arch Intern Med 159:167-173. https:// doi.org/10.1001/archinte.159.2.167

39. Boulos A, Rolain J-M, Raoult D (2004) Antibiotic susceptibility of Tropheryma whipplei in MRC5 cells. Antimicrob Agents Chemother 48:747-752. https://doi.org/10.1128/AAC. 48.3.747-752.2004

40. Rolain J-M, Colson P, Raoult D (2007) Recycling of chloroquine and its hydroxyl analogue to face bacterial, fungal and viral infections in the 21st century. Int J Antimicrob Agents 30:297-308. https://doi.org/10.1016/j.ijantimicag.2007.05.015

41. Tsiang H, Superti F (1984) Ammonium chloride and chloroquine inhibit rabies virus infection in neuroblastoma cells. Adv Virol 81:377-382. https://doi.org/10.1007/BF01310010

42. Kwiek JJ, Haystead TA, Rudolph J (2004) Kinetic mechanism of quinone oxidoreductase 2 and its inhibition by the antimalarial quinolines. Biochemistry 43:4538-4547. https://doi.org/ 10.1021/bi035923w

43. Varki A (1997) Sialic acids as ligands in recognition phenomena. FASEB J 11(4):248-255. https://doi.org/10.1096/fasebj. 11.4.9068613

44. Olofsson S, Kumlin U, Dimock K, Arnberg N (2005) Avian influenza and sialic acid receptors: more than meets the eye? Lancet Infect Dis 5(3):184-188. https://doi.org/10.1016/ S1473-3099(05)01311-3

45. Zhuang M-W, Cheng Y, Zhang J, Jiang X-M, Wang L, Deng J, Wang P-H (2020) Increasing host cellular receptor-angiotensin-converting enzyme 2 expression by coronavirus may facilitate 2019-nCoV (or SARS-CoV-2) infection. J Med Virol 92:2693-2701. https://doi.org/10.1002/jmv.26139

46. Tricou V, Minh NN, Van TP, Lee SJ, Farrar J, Wills B et al (2010) A randomized controlled trial of chloroquine for the treatment of dengue in Vietnamese adults. PLoS Negl Trop Dis 4:e785. https://doi.org/10.1371/journal.pntd.0000785

47. Gay B, Bernard E, Solignat M, Chazal N, Devaux C, Briant L (2012) pH-dependent entry of chikungunya virus into Aedes albopictus cells. Infect Genet Evol 12:1275-1281. https://doi. org/10.1016/j.meegid.2012.02.003
48. Savarino A, Gennero L, Sperber K, Boelaert J (2001) The antiHIV-1 activity of chloroquine. J Clin Virol 20:131-135. https:// doi.org/10.1016/S1386-6532(00)00139-6

49. Mingo RM, Simmons JA, Shoemaker CJ et al (2015) Ebola virus and severe acute respiratory syndrome coronavirus display late cell entry kinetics: evidence that transport to NPC1+ endolysosomes is a rate-defining step. J Virol 89:2931-2943. https://doi. org/10.1128/JVI.03398-14

50. Pastick KA, Okafor EC, Wang F, Lofgren SM, Skipper CP, Nicol MR, Pullen MF, Rajasingham R, McDonald EG, Lee TC, Schwartz IS (2020) Hydroxychloroquine and chloroquine for treatment of SARS-CoV-2 (COVID-19). Open Forum Infect Dis 7:ofaa130. https://doi.org/10.1093/ofid/ofaa130

51. Savarino A, Lucia MB, Rastrelli E, Rutella S, Golotta C, Morra E et al (2004) Anti-HIV effects of chloroquine: inhibition of viral particle glycosylation and synergism with protease inhibitors. J Acquir Immune Defic Syndr 35:223-232. https://doi.org/10. 1097/00126334-200403010-00002

52. Accapezzato D, Visco V, Francavilla V, Molette C, Donato T, Paroli M et al (2005) Chloroquine enhances human CD8+ T cell responses against soluble antigens in vivo. J Exp Med 202:817828. https://doi.org/10.1084/jem.20051106

53. Savarino A, Di Trani L, Donatelli I, Cauda R, Cassone A (2006) New insights into the antiviral effects of chloroquine. Lancet Infect Dis 6:67-69. https://doi.org/10.1016/S1473-3099(06) 70361-9

54. Yang Y-p, Hu L-f, Zheng H-f et al (2013) Application and interpretation of current autophagy inhibitors and activators. Acta Pharmacol Sin 34:625-635. https://doi.org/10.1038/aps.2013.5

55. Levy JMM, Towers CG, Thorburn A (2017) Targeting autophagy in cancer. Nat Rev Cancer 17:528-542. https://doi.org/10.1038/ nrc. 2017.53

56. Liu J, Cao R, Xu M, Wang X, Zhang H, Hu H, Li Y, Hu Z, Zhong W, Wang M (2020) Hydroxychloroquine, a less toxic derivative of chloroquine, is effective in inhibiting SARS-CoV-2 infection in vitro. Cell Discov 6:16. https://doi.org/10.1038/ s41421-020-0156-0

57. Seitz M, Valbracht J, Quach J, Lotz M (2003) Gold sodium thiomalate and chloroquine inhibit cytokine production in monocytic THP-1 cells through distinct transcriptional and posttranslational mechanisms. J Clin Immunol 23:477-484. https://doi.org/10. 1023/B:JOCI.0000010424.41475.17

58. Schrezenmeier E, Dörner T (2020) Mechanisms of action of hydroxychloroquine and chloroquine: implications for rheumatology. Nat Rev Rheumatol 16:1-12. https://doi.org/10.1038/ s41584-020-0372-x

59. Briant L, Robert-Hebmann V, Acquaviva C, Pelchen-Matthews A, Marsh M, Devaux C (1998) The protein tyrosine kinase p56 lck is required for triggering NF- $\kappa B$ activation upon interaction of human immunodeficiency virus type 1 envelope glycoprotein gp120 with cell surface CD4. J Virol 72:6207-6214. https://doi. org/10.1128/JVI.72.7.6207-6214.1998

60. Brumlik MJ, Nkhoma S, Kious MJ, Thompson GR 3rd, Patterson TF, Siekierka JJ, Anderson TJ, Curiel TJ (2011) Human p38 mitogen-activated protein kinase inhibitor drugs inhibit Plasmodium falciparum replication. Exp Parasitol 128:170-175. https:// doi.org/10.1016/j.exppara.2011.02.016

61. Kim K-A, Park J-Y, Lee J-S, Lim S (2003) Cytochrome P450 2C8 and CYP3A4/5 are involved in chloroquine metabolism in human liver microsomes. Arch Pharmacal Res 26:631-637. https://doi. org/10.1007/BF02976712

62. Tulpule A, Krishnaswamy K (1982) Effect of food on bioavailability of chloroquine. Eur J Clin Pharmacol 23:271-273. https:// doi.org/10.1007/BF00547567

63. Augustijns P, Geusens P, Verbeke N (1992) Chloroquine levels in blood during chronic treatment of patients with rheumatoid 
arthritis. Eur J Clin Pharmacol 42:429-433. https://doi.org/10. 1007/BF00280130

64. Frisk-Holmberg M, Bergqvist Y, Termond E, Domeij-Nyberg B (1984) The single dose kinetics of chloroquine and its major metabolite desethylchloroquine in healthy subjects. Eur J Clin Pharmacol 26:521-530. https://doi.org/10.1007/BF00542151

65. Gustafsson L, Walker O, Alvan G, Beermann B, Estevez F, Gleisner L et al (1983) Disposition of chloroquine in man after single intravenous and oral doses. Br J Clin Pharmacol 15:471-479. https://doi.org/10.1111/j.1365-2125.1983.tb01532.x

66. De Vries P, Oosterhuis B, Van Boxtel C (1994) Single-dose pharmacokinetics of chloroquine and its main metabolite in healthy volunteers. Drug Investig 8:143-149. https://doi.org/10.1007/ BF03259430

67. Mackenzie AH (1983) Pharmacologic actions of 4-aminoquinoline compounds. Am J Med 75:5-10. https://doi.org/10.1016/ 0002-9343(83)91264-0

68. Wetsteyn J, De Vries P, Oosterhuis B, Van Boxtel C (1995) The pharmacokinetics of three multiple dose regimens of chloroquine: implications for malaria chemoprophylaxis. Br J Clin Pharmacol 39:696-699. https://doi.org/10.1111/j.1365-2125. 1995.tb05731.x

69. Grundmann M, Mikulikova I, Vrublovský P (1971) Tissue distribution of subcutaneously administered chloroquine in the rat. Arzneimittelforschung 21:573. PMID: 5108164

70. McChesney E-W, Conway W, Banks W, Rogers J, Shekosky J, Grace A et al (1966) Studies of the metabolism of some compounds of the 4-amino-7-chloroquinoline series. J Pharmacol Exp Ther 151:482-493. PMID: 4957157

71. Gustafsson L, Lindstrom B, Grahnen A, Alvan G (1987) Chloroquine excretion following malaria prophylaxis. Br J Clin Pharmacol 24:221-224. https://doi.org/10.1111/j.1365-2125.1987.tb031 65. $\mathrm{x}$

72. Ette EI, Essien EE, Thomas WO, Brown-Awala EA (1989) Pharmacokinetics of chloroquine and some of its metabolites in healthy volunteers: a single dose study. J Clin Pharmacol 29:457-462. https://doi.org/10.1128/AAC.01269-09

73. Ofori-Adjei D, Ericsson O (1985) Chloroquine in nail clippings. Lancet 2:331. https://doi.org/10.1016/S0140-6736(85)90377-0

74. Ladipo G, Essien E, Andy J (1983) Complete heart block in chronic chloroquine poisoning. Int J Cardiol 4:198-200. https:// doi.org/10.1016/0167-5273(83)90136-5

75. Essien E, Ette E (1986) Effects of chloroquine and didesethylchloroquine on rabbit myocardium and mitochondria. J Pharm Pharmacol 38:543-546. https://doi.org/10.1111/j.2042-7158. 1986.tb04620.x

76. Han Y, Pham HT, Xu H, Quan Y, Mesplède T (2019) Antimalarial drugs and their metabolites are potent Zika virus inhibitors. J Med Virol 91:1182-1190. https://doi.org/10.1002/jmv.25440

77. Bourrié M, Meunier V, Berger Y, Fabre G (1996) Cytochrome $\mathrm{P} 450$ isoform inhibitors as a tool for the investigation of metabolic reactions catalyzed by human liver microsomes. J Pharmacol Exp Ther 277:321-332. PMID: 8613937

78. McChesney E, Fasco M, Banks W, Kersch TB (1967) The metabolism of chloroquine in man during and after repeated oral dosage. J Pharmacol Exp Ther 158:323-331. PMID: 6065153

79. Somer M, Kallio J, Pesonen U, Pyykkö K, Huupponen R, Scheinin M (2000) Influence of hydroxychloroquine on the bioavailability of oral metoprolol. Br J Clin Pharmacol 49:549-554. https://doi.org/10.1046/j.1365-2125.2000.00197.x

80. Kolars JC, Schmiedlin-Ren P, Schuetz JD, Fang C, Watkins PB (1992) Identification of rifampin-inducible P450IIIA4 (CYP3A4) in human small bowel enterocytes. J Clin Investig 90:1871-1878. https://doi.org/10.1172/JCI116064
81. Thorogood N, Atwal S, Mills W, Jenner M, Lewis D, Cavenagh $\mathrm{J}$ et al (2007) The risk of antimalarials in patients with renal failure. Postgrad Med J 83:8. https://doi.org/10.1136/pgmj.2007. 063735

82. Mohan D, Mohandas E, Rajat R (1981) Chloroquine psychosis: a chemical psychosis? J Natl Med Assoc 73:1073. PMID: 7310924

83. Bhatia M (1991) Chloroquine-induced psychiatric complications. Br J Psychiatry 159:735. https://doi.org/10.1192/bjp.159.5.735

84. Das P, Rai A, Chopra A, Philbrick K (2014) Psychosis likely induced by hydroxychloroquine in a patient with chronic $\mathrm{Q}$ fever: a case report and clinically relevant review of pharmacology. Psychosomatics 55:409-413. https://doi.org/10.1016/j.psym. 2013.06.017

85. Hsu W, Chiu N, Huang S (2011) Hydroxychloroquine-induced acute psychosis in a systemic lupus erythematosus female. Acta Neuropsychiatr 23:318-319. https://doi.org/10.1111/j.16015215.2011.00575.x

86. de Olano J, Howland MA, Su MK, Hoffman RS, Biary R (2019) Toxicokinetics of hydroxychloroquine following a massive overdose. Am J Emerg Med 37:2264.e5-2264.e8. https://doi.org/10. 1016/j.ajem.2019.158387

87. Hughes JT, Esiri M, Oxbury J, Whitty C (1971) Chloroquine myopathy. QJM Int J Med 40:85-93. PMID: 4253656

88. Sanghvi L, Mathur B (1965) Electrocardiogram after chloroquine and emetine. Circulation 32:281-289. https://doi.org/10.1161/01. CIR.32.2.281

89. Jaeger A, Sauder P, Kopferschmitt J, Flesch F (1987) Clinical features and management of poisoning due to antimalarial drugs. Med Toxicol Adverse Drug Exp 2:242-273. https://doi.org/10. 1007/BF03259868

90. Toennesmann E, Stroehmann I, Kandolf R, Wolburg H, Strach K, Musshoff F et al (2012) Cardiomyopathy caused by longterm treatment with chloroquine: a rare disease, or a rare diagnosis? J Rheumatol 39:1099-1103. https://doi.org/10.3899/jrheum. 110959

91. Cervera A, Espinosa G, Cervera R, Font J, Ingelmo M (2001) Cardiac toxicity secondary to long term treatment with chloroquine. Ann Rheum Dis 60:301-302. https://doi.org/10.1136/ard. 60.3.301

92. Yogasundaram H, Putko BN, Tien J, Paterson DI, Cujec B, Ringrose $\mathrm{J}$ et al (2014) Hydroxychloroquine-induced cardiomyopathy: case report, pathophysiology, diagnosis, and treatment. Can J Cardiol 30:1706-1715. https://doi.org/10.1016/j.cjca.2014. 08.016

93. Yogasundaram H, Hung W, Paterson ID, Sergi C, Oudit GY (2018) Chloroquine-induced cardiomyopathy: a reversible cause of heart failure. ESC Heart Fail 5:372-375. https://doi.org/10. 1002/ehf2.12276

94. Yam J, Kwok A (2006) Ocular toxicity of hydroxychloroquine. Hong Kong Med J 12:294. PMID: 16912357

95. Marmor MF, Kellner U, Lai TY, Lyons JS, Mieler WF (2011) Revised recommendations on screening for chloroquine and hydroxychloroquine retinopathy. Ophthalmology 118:415-422. https://doi.org/10.1016/j.ophtha.2010.11.017

96. Marmor MF, Kellner U, Lai TY, Melles RB, Mieler WF (2016) Recommendations on screening for chloroquine and hydroxychloroquine retinopathy (2016 revision). Ophthalmology 123:1386-1394. https://doi.org/10.1016/j.ophtha.2016.01.058

97. Costedoat-Chalumeau N, Dunogué B, Leroux G, Morel N, Jallouli M, Le Guern V et al (2015) A critical review of the effects of hydroxychloroquine and chloroquine on the eye. Clin Rev Allergy Immunol 49:317-326. https://doi.org/10.1007/ s12016-015-8469-8

98. Back DJ, Purba HS, Staiger C, Orme MLE, Breckenridge AM (1983) Inhibition of drug metabolism by the antimalarial drugs 
chloroquine and primaquine in the rat. Biochem Pharmacol 32:257-263. https://doi.org/10.1007/BF03188819

99. Becker K, Tilley L, Vennerstrom JL, Roberts D, Rogerson S, Ginsburg H (2004) Oxidative stress in malaria parasite-infected erythrocytes: host-parasite interactions. Int J Parasitol 34:163189. https://doi.org/10.1016/j.ijpara.2003.09.011

100. Giovanella F, Ferreira GK, Prá SDD, Carvalho-Silva M, Gomes LM, Scaini G et al (2015) Effects of primaquine and chloroquine on oxidative stress parameters in rats. An Acad Bras Ciênc 87:1487-1496.https://doi.org/10.1590/0001-3765201520140637

101. Olatunde Farombi E, Shyntum YY, Emerole GO (2003) Influence of chloroquine treatment and Plasmodium falciparum malaria infection on some enzymatic and non-enzymatic antioxidant defense indices in humans. Drug Chem Toxicol 26:59-71. https://doi.org/10.1081/DCT-120017558

102. Shadnia S, Ebadollahi-Natanzi A, Ahmadzadeh S, KaramiMohajeri S, Pourshojaei Y, Rahimi HR (2018) Delayed death following paraquat poisoning: three case reports and a literature review. Toxicol Res 7:745-753. https://doi.org/10.1039/c8tx0 0120k.3

103. Reghunathan R, Jayapal M, Hsu L-Y, Chng H-H, Tai D, Leung BP et al (2005) Expression profile of immune response genes in patients with severe acute respiratory syndrome. BMC Immunol 6:2. https://doi.org/10.1186/1471-2172-6-2

104. Omotosho O, Adebiyi M, Oyeyemi M (2014) Comparative study of the haematology and serum biochemistry of male wistar rats treated with chloroquine and artesunate. J Physiol Pharmacol Adv 4:413-419. https://doi.org/10.5455/jppa.20140827112119

105. Clemessy JL, Favier C, Borron SW, Hantson PE, Vicaut E, Baud FJ (1995) Hypokalaemia related to acute chloroquine ingestion. Lancet 346:877-880. https://doi.org/10.1016/S0140-6736(95) 92711-5

106. Goyal V, Bordia A (1995) The hypoglycemic effect of chloroquine. J Assoc Physicians India 43:17-18. PMID: 9282631

107. Powrie J, Smith G, Shojaee-Moradie F, Sonksen P, Jones R (1991) Mode of action of chloroquine in patients with noninsulin-dependent diabetes mellitus. Am J Physiol Endocrinol Metab 260:E897-E904. https://doi.org/10.1152/ajpendo.1991. 260.6.E897

108. Schaer CA, Laczko E, Schoedon G, Schaer DJ, Vallelian F (2013) Chloroquine interference with hemoglobin endocytic trafficking suppresses adaptive heme and iron homeostasis in macrophages: the paradox of an antimalarial agent. Oxid Med Cell Longev 2013:870472. https://doi.org/10.1155/2013/870472

109. Singhi S, Singhi P, Singh M (1979) Extrapyrbmidal syndrome following chloroquine therapy. Indian J Pediatr 46:58-60. https:// doi.org/10.1007/BF02811499

110. Pukrittayakamee $S$, Tarning J, Jittamala $P$, Charunwatthana $P$, Lawpoolsri S, Lee SJ et al (2014) Pharmacokinetic interactions between primaquine and chloroquine. Antimicrob Agents Chemother 58:3354-3359. https://doi.org/10.1128/AAC.02794-13

111. Wang C, Fortin P, Li Y, Panaritis T, Gans M, Esdaile J (1999) Discontinuation of antimalarial drugs in systemic lupus erythematosus. J Rheumatol 26:808-815.PMID: 10229401

112. Seçkin U, Ozoran K, Ikinciogullari A, Borman P, Bostan EE (2000) Hydroxychloroquineototoxicity in a patient with rheumatoid arthritis. Rheumatol Int 19:203-204. https://doi.org/10. 1007/s002960000054

113. Izmirly PM, Costedoat-Chalumeau N, Pisoni CN, Khamashta MA, Kim MY, Saxena A et al (2012) Maternal use of hydroxychloroquine is associated with a reduced risk of recurrent antiSSA/Ro-antibody-associated cardiac manifestations of neonatal lupus. Circulation 126:76-82. https://doi.org/10.1161/CIRCU LATIONAHA.111.089268

114. Lisney AR, Szelinski F, Reiter K, Burmester GR, Rose T, Dörner T (2017) High maternal expression of SIGLEC1 on monocytes as a surrogate marker of a type I interferon signature is a risk factor for the development of autoimmune congenital heart block. Ann Rheum Dis 76:1476-1480. https://doi.org/10.1136/annrh eumdis-2016-210927

115. Lacroix I, Bénévent J, Damase-Michel C (2020) Chloroquine and hydroxychloroquine during pregnancy: what do we know? Therapie 75:384-385. https://doi.org/10.1016/j.jinf.2020.05.004

116. Zhao X, Jiang Y, Zhao Y, Xi H, Liu C, Qu F et al (2020) Analysis of the susceptibility to COVID-19 in pregnancy and recommendations on potential drug screening. Eur J Clin Microbiol Infect Dis 23:1-12. https://doi.org/10.1007/s10096-020-03897-6

117. Saghir SAM, AlGabri NA, Alagawany MM, Attia YA, Alyileili SR, Elnesr SS, Shafi ME, Al-shargi OYA, Al-balagi N, Alwajeeh AS, Alsalahi OS, Patra AK, Khafaga AF, Negida A, Noreldin A, Al-Amarat W, Almaiman AA, El-Tarabily KA, Abd El-Hack ME (2021) Chloroquine and hydroxychloroquine for the prevention and treatment of COVID-19: a fiction, hope or hype? An updated review. Ther Clin Risk Manag 17:371-387. https://doi.org/10. 2147/TCRM.S301817

118. Fossa AA, Wisialowski T, Duncan JN, Deng S, Dunne M (2007) Azithromycin/chloroquine combination does not increase cardiac instability despite an increase in monophasic action potential duration in the anesthetized guinea pig. Am J Trop Med Hyg 77:929-938. PMID: 17984356

119. Tiberghien F, Loor F (1996) Ranking of P-glycoprotein substrates and inhibitors by a calcein-AM fluorometry screening assay. Anticancer Drugs 7:568-578. https://doi.org/10.1097/00001 813-199607000-00012

120. Nampoory N, Nessim J, Gupta RK, Johny KV (1992) Drug interaction of chloroquine with ciclosporin. Nephron 62:108-109. https://doi.org/10.1159/000187007

121. Lee JY, Vinayagamoorthy N, Han K, Kwok SK, Ju JH, Park KS et al (2016) Association of polymorphisms of cytochrome P450 2D6 with blood hydroxychloroquine levels in patients with systemic lupus erythematosus. Arthritis Rheumatol 68:184-190. https://doi.org/10.1002/art.39402

122. Furst DE (1996) Pharmacokinetics of hydroxychloroquine and chloroquine during treatment of rheumatic diseases. Lupus 5:S11-S15. PMID: 8803904

123. Leppert W (2011) CYP2D6 in the metabolism of opioids for mild to moderate pain. Pharmacology 87:274-285. https://doi.org/10. $1159 / 000326085$

124. Projean D, Baune B, Farinotti R, Flinois JP, Beaune P, Taburet AM, Ducharme J (2003) In vitro metabolism of chloroquine: identification of CYP2C8, CYP3A4, and CYP2D6 as the main isoforms catalyzing $N$-desethylchloroquine formation. Drug Metab Dispos 31:748-754. https://doi.org/10.1124/dmd.31.6.748

125. Ahmed MH, Ashton N, Balment RJ (2003) Renal function in a rat model of analgesic nephropathy: effect of chloroquine. $\mathbf{J}$ Pharmacol Exp Ther 305:123-130. https://doi.org/10.1124/jpet. 102.047233

126. Musabayane C, Cooper R, Osim E, Balment R (2000) Renal electrolyte and fluid handling in the rat following chloroquine and/ or ethanol administration. Gen Pharmacol Vasc Syst 34:43-51. https://doi.org/10.1016/S0306-3623(00)00045-8

127. Musabayane CT, Cooper RG, Rao PVVP, Balment RJ (2000) Effects of ethanol on the changes in renal fluid and electrolyte handling and kidney morphology induced by long-term chloroquine administration to rats. Alcohol 22:129-138. https://doi.org/ 10.1016/S0741-8329(00)00110-5

128. Seferović P, Ristić A, Maksimović R, Simeunović D, Ristić G, Radovanović $\mathrm{G}$ et al (2006) Cardiac arrhythmias and conduction disturbances in autoimmune rheumatic diseases. Rheumatology 45:iv39-iv42. https://doi.org/10.1093/rheumatology/kel315

129. Melles RB, Marmor MF (2014) The risk of toxic retinopathy in patients on long-term hydroxychloroquine therapy. JAMA 
Ophthalmol 132:1453-1460. https://doi.org/10.1001/jamaophtha lmol.2014.3459

130. Marmor MF, Hu J (2014) Effect of disease stage on progression of hydroxychloroquine retinopathy. JAMA Ophthalmol 132:1105-1112. https://doi.org/10.1001/jamaophthalmol.2014. 1099

131. Riou B, Barriot P, Rimailho A, Baud FJ (1988) Treatment of severe chloroquine poisoning. N Engl J Med 318:1-6. https:// doi.org/10.1056/NEJM198801073180101

132. Britton W, Kevau I (1978) Intentional chloroquine overdosage. Med J Aust 2:407-410. https://doi.org/10.5694/j.1326-5377. 1978.tb76816.x

133. Clemessy J-L, Taboulet P, Hoffman JR, Hantson P, Barriot P, Bismuth C et al (1996) Treatment of acute chloroquine poisoning: a 5-year experience. Crit Care Med 24:1189-1195. https:// doi.org/10.1097/00003246-199607000-00021

134. Juurlink DN (2020) Safety considerations with chloroquine, hydroxychloroquine and azithromycin in the management of SARS-CoV-2 infection. CMAJ 192:E450-E453. https://doi.org/ 10.1503/cmaj.200528

135. Murugavel P, Pari L (2004) Attenuation of chloroquine-induced renal damage by $\alpha$-lipoic acid: possible antioxidant mechanism. Ren Fail 26:517-524. https://doi.org/10.1081/JDI-200031761

136. Boyle PJ, Justice K, Krentz AJ, Nagy RJ, Schade DS (1993) Octreotide reverses hyperinsulinemia and prevents hypoglycemia induced by sulfonylurea overdoses. J Clin Endocrinol Metab 76:752-756. https://doi.org/10.1210/jcem.76.3.8445035

137. Maxwell NM, Nevin RL, Stahl S, Block J, Shugarts S, Wu AH et al (2015) Prolonged neuropsychiatric effects following management of chloroquine intoxication with psychotropic polypharmacy. Clin Case Rep 3:379. https://doi.org/10.1002/ccr3.238

138. Zhou P, Yang X-L, Wang X-G, Hu B, Zhang L, Zhang W et al (2020) A pneumonia outbreak associated with a new coronavirus of probable bat origin. Nature 579:270-273. https://doi.org/10. 1038/s41586-020-2012-7

139. Paton NI, Lee L, Xu Y, Ooi EE, Cheung YB, Archuleta S et al (2011) Chloroquine for influenza prevention: a randomised, double-blind, placebo controlled trial. Lancet Infect Dis 11:677-683. https://doi.org/10.1016/s1473-3099(11)70065-2
140. Ooi EE, Chew JSW, Loh JP, Chua RC (2006) In vitro inhibition of human influenza A virus replication by chloroquine. Virol $\mathrm{J}$ 3:39. https://doi.org/10.1186/1743-422X-3-39

141. Gautret P, Lagier J-C, Parola P, Meddeb L, Mailhe M, Doudier $B$ et al (2020) Hydroxychloroquine and azithromycin as a treatment of COVID-19: results of an open-label non-randomized clinical trial. Int J Antimicrob Agents 56:105949. https://doi.org/ 10.1016/j.jjantimicag.2020.105949

142. Kim A, Sparks J, Liew J, Putman M, Berenbaum F, Duarte-Garcia A, COVID-19 Global Rheumatology Alliance et al (2020) A rush to judgment? Rapid reporting and dissemination of results and its consequences regarding the use of hydroxychloroquine for COVID-19. Ann Intern Med 30:M20-1223. https://doi.org/ 10.7326/M20-1223

143. Chen J, Liu D, Liu L, Liu P, Xu Q, Xia L et al (2020) A pilot study of hydroxychloroquine in treatment of patients with common coronavirus disease-19 (COVID-19). J Zhejiang Univ (Med Sci) 49:215-219. https://doi.org/10.3785/j.issn.1008-9292.2020. 03.03

144. Cortegiani A, Ingoglia G, Ippolito M, Giarratano A, Einav S (2020) A systematic review on the efficacy and safety of chloroquine for the treatment of COVID-19. J Crit Care 27:279-283. https://doi.org/10.1016/j.jcrc.2020.03.005

145. Huang M, Tang T, Pang P, Li M, Ma R, Lu J et al (2020) Treating COVID-19 with chloroquine. J Mol Cell Biol 12:322-325. https://doi.org/10.1093/jmcb/mjaa014

146. Mercuro NJ, Yen CF, Shim DJ, Maher TR, McCoy CM, Zimetbaum PJ et al (2020) Risk of QT interval prolongation associated with use of hydroxychloroquine with or without concomitant azithromycin among hospitalized patients testing positive for Coronavirus Disease 2019 (COVID-19). JAMA Cardiol 5:10361041. PMID: 32936252

147. Bessiere F, Roccia H, Deliniere A, Charriere R, Chevalier P, Argaud L et al (2020) Assessment of QT intervals in a case series of patients with Coronavirus disease 2019 (COVID-19) infection treated with hydroxychloroquine alone or in combination with azithromycin in an intensive care Unit. JAMA Cardiol 5:10671069. https://doi.org/10.1001/jamacardio.2020.1787 